\section{Inherited Incomplete Deficiency of the Fourth Component of Complement (C4) Determined by a Gene Not Linked to Human Histocompatibility Leukocyte Antigens}

\author{
W. Angus Muir, Sterling Hedrick, Chester A. Alper, \\ Oscar D. Ratnoff, Bernice Schacter, \\ and Jeffrey J. Wisnieski \\ Departments of Medicine and Pathology, Case Western Reserve \\ University, Cleveland, Ohio 44106; Veterans Administration \\ Medical Center, Cleveland, Ohio 46220; The Center for Blood \\ Research and Children's Hospital Medical Center, and \\ Department of Pediatrics, Harvard Medical School, Boston, \\ Massachusetts 02115
}

bstract. We have studied a family in which the proband had systemic lupus erythematosus and selective incomplete deficiency of the fourth component of complement (C4) (2-5\% of the normal level). An additional six healthy family members also had low $\mathrm{C} 4$ levels (2.4-24.1\% of normal) but no evidence of lupus. This form of inherited $\mathrm{C} 4$ deficiency differs from that in previously reported families in that inheritance was autosomal dominant (rather than recessive), C4 levels were markedly reduced (but not undetectable), and there was no linkage to HLA, BF, or C4 structural loci, all known to be within the major histocompatibility complex.

\section{Introduction}

Nine unrelated individuals have been described who lack detectable levels of the fourth component of serum complement (C4) ${ }^{1}$ by functional and immunochemical measurements. The first patient, described by Hauptmann and co-workers (1), was an 18-yr-old girl with systemic lupus erythematosus. HLA

Dr. Ratnoff is a Career Investigator of the American Heart Association. Received for publication 3 February 1984 and in revised form 18 June 1984.

1. Abbreviations used in this paper: $\mathrm{C} 4$, fourth component of complement; $\mathrm{CH} 50$, hemolytic complement; $\mathrm{CIC}$, circulating immune complexes; $\mathrm{PGM}_{3}$, phosphoglucomutase-3.

J. Clin. Invest.

(c) The American Society for Clinical Investigation, Inc.

$0021-9738 / 84 / 10 / 1509 / 06 \quad \$ 1.00$

Volume 74, October 1984, 1509-1514 typing of this family suggested linkage between the C4-deficiency gene and the major histocompatibility complex (MHC) (2). Most subsequent cases of C4 deficiency (3-10) have had systemic lupus or lupuslike disease.

C4 in man is synthesized under the direction of two distinct but very closely linked loci (11), designated $C 4 A$ and $C 4 B$. Half-null haplotypes containing $C 4 A^{*} Q O$ (quantity zero) or $C 4 B^{*} Q O$ are common in caucasians (12) and can best be detected in family studies by neuraminidase treatment of serum or plasma and crossed immunoelectrophoresis (13). By immunofixation of agarose gel electrophoresis of neuraminidasetreated samples, extensive structural genetic polymorphism can be recognized at both the $C 4 A$ and $C 4 B$ loci (14). The products of $C 4 A$ and $C 4 B$ differ in serological reactivity in that $\mathrm{C} 4 \mathrm{~A}$ variants are Rodgers positive and $\mathrm{C} 4 \mathrm{~B}$ variants are Chido positive (12). Under certain conditions, $C 4 B$ has hemolytic activity whereas C4A does not (14). In general, C4A variants tend to be more acidic than $C 4 B$ variants and the chain of C4A variants is of slower mobility than that of C4B variants on sodium dodecyl sulfate (SDS) gel electrophoresis (15).

When C4 typing was performed in a family with a child with classical C4 deficiency (16), it was shown conclusively that the deficiency resulted from homozygosity for a doublenull C4 haplotype, $C 4 A^{*} Q 0, C 4 B^{*} Q 0$, closely linked to other loci of the MHC, including HLA. Subsequent studies have confirmed these findings $(10,17)$.

We have studied a 26-yr-old woman with lupus erythematosus and persistent hypocomplementemia. She appears to have a selective incomplete deficiency of $\mathrm{C} 4$. Her erythrocytes were positive for Rodgers and Chido antigens. 22 members of her family were studied and six relatives (of 13 at risk) were also found to have a selective deficiency of C4. HLA, BF, and C4 typing of the family did not reveal any association or 
linkage between the gene or genes determining $\mathrm{C} 4$ deficiency in this family and the major histocompatibility complex.

\section{Methods}

Case study. A 26-yr-old woman was referred for evaluation of migratory polyarthritis, rash, and alopecia. Subsequently, she began to have attacks of headache, blurred vision, and scintillating scotomata. At first, headaches were associated with right, and later with left transient hemiparesis. On each occasion, cerebrospinal fluid, skull $\mathrm{x}$ rays, brain scans, and computed tomography were normal and her symptoms improved on high dose prednisone therapy. Antinuclear antibody was positive at 1:10 to 1:100 dilution, anti-DNA was weakly positive, and hemolytic complement (CH50) ranged from 5 to 60 units (normal $=100 \pm 20$ [1 SD]). Renal function was normal on repeated testing. Fibromuscular hyperplasia of the right internal carotid artery was detected by arteriography and required surgical correction. During disease activity, $\mathrm{CH} 50, \mathrm{C} 3$, and $\mathrm{C} 4$ were all decreased, whereas during periods of remission, $\mathrm{C} 3$ returned to normal but $\mathrm{C} 4$ remained at $5 \%$ of normal or less and $\mathrm{CH} 50$ increased but not to normal. A diagnosis of systemic lupus erythematosus was made. 22 family members from three generations were available for study. Six of these individuals were found to have reduced concentrations of $\mathrm{C} 4$. None had increased susceptibility to infection, a bleeding tendency, or rheumatic disease.

Fully informed consent was obtained from each individual before the collection of blood samples.

Complement assays. Blood was allowed to clot in glass tubes for $30 \mathrm{~min}$ at room temperature, placed at $4^{\circ} \mathrm{C}$ for $30 \mathrm{~min}$, and then centrifuged for $5 \mathrm{~min}$ at $3,500 \mathrm{~g}$. The separated serum was used immediately or kept frozen at $-70^{\circ} \mathrm{C}$ until assayed. Plasma samples for measurement of $\mathrm{C} 3$ and $\mathrm{C} 4$ were drawn into $\mathrm{Na}_{2} \mathrm{EDTA}$, maintained at $37^{\circ} \mathrm{C}$ for $30 \mathrm{~min}$ and centrifuged and separated at $37^{\circ} \mathrm{C}$ before testing. CH50 titrations were performed by standard methods (18). C3 and $\mathrm{C} 4$ were measured by radial immunodiffusion using Hyland Laboratory, Costa Mesa, CA (C3) and Meloy Laboratory, Springfield, VA (C4) plates, respectively. Normal ranges were established in 25 healthy donors. Stoichiometric hemolytic titrations of $\mathrm{C1}, \mathrm{C4}$, and $\mathrm{C} 2$ were performed by the methods of Rapp and Borsos (18) and for C3 through C9 by the methods of Nelson et al. (19), as modified by Rosenfeld et al. (20). Hemolytic titrations of $\mathrm{Cl}$ and $\mathrm{C} 4$ were also performed on mixtures of normal human serum and serum from the proband drawn during a period of inactive disease. The concentrations of factor B, prosperdin, $\beta-1-\mathrm{H}, \mathrm{C} 4$ binding protein, and $\mathrm{C} \overline{1}$ inhibitor were determined by electroimmunoassay (21). $C \overline{1}$ inhibitor was also measured by an esterolytic assay (22) and its charge was analyzed by immunofixation after agarose gel electrophoresis. Sera were tested for circulating immune complexes (CIC) by the method of Zubler et al. (23).

Analysis of C4, BF, and HLA haplotypes. Desialated plasma samples were subjected to crossed immunoelectrophoresis for detection of null alleles at the $C 4 A$ and $C 4 B$ loci, as described previously (13). To detect C4 structural variants, desialated plasma samples were subjected to immunofixation electrophoresis in $0.75 \%$ agarose as previously described (14). C4 subunit size was analyzed by immunoprecipitation with anti-C4 on SDS-polyacrylamide gels (15). HLA typing for antigens at the HLA-A, B, C, and D loci was performed by a modified micromethod (24). The method for isolating B lymphocytes was according to Lowry (25). Plasma samples were subjected to agarose gel electrophoresis and immunofixation (26) with goat antiserum to human factor B (Atlantic Antibodies, Scarborough, ME) for BF typing. C2 types were determined by isoelectric focusing (27).
Additional genetic markers. Phenotypes of erythrocyte glyoxalase I (28) and white cell phosphoglucomutase-3 (PGM $\left.{ }_{3}\right)(29)$ were determined by starch gel electrophoresis.

Blood clotting studies. The methods used for measurement of the platelet count, clotting time, prothrombin time, and partial thromboplastin time, and for the assay of clotting factors and inhibitors are summarized elsewhere $(30,31)$. The bleeding time was measured by a modification of Duke's Methods (32), and clot retraction by a semiquantitative technique (33). Platelet retention by glass bead columns was tested by Salzman's (34) method and platelet factor 3 release by Spaet and Cintron's (35) technique. The agglutination of platelets by ristocetin, and aggregation of platelets by various agents were studied by the methods recommended by the manufacturer of Platelet Aggregation Profile, model PAP-2A (Bio/Data Corp., Hatboro, PA), adding 1:10 volume of ristocetin $(15 \mathrm{mg} / \mathrm{ml}$ water, Pacific Hemostasis Lab., Bakersfield, CA), collagen $0.7 \mathrm{mg} / \mathrm{ml}$ in $0.15 \mathrm{M}$ sodium chloride, (the gift of the late Dr. Howard Bensusan), adenosine diphosphate (ADP, $2 \times 10^{-5} \mathrm{M}$ in $0.15 \mathrm{M}$ sodium chloride, Sigma Chemical Co., St. Louis, $\mathrm{MO})$, epinephrine $\left(10^{-4} \mathrm{M}\right.$ in $0.15 \mathrm{M}$ sodium chloride, Sigma Chemical Co.), bovine thrombin (1.0 National Institutes of Health $\mathrm{U} / \mathrm{ml}$ barbitalsaline buffer, Parke-Davis Co., Detroit, MI) or zymosan $(6.7 \mathrm{mg} / \mathrm{ml}$ in $0.15 \mathrm{M}$ sodium chloride, Sigma Chemical Co.) to $9 \mathrm{vol}$ of platelet-rich citrated plasma $(250,000 / \mu \mathrm{l})$.

\section{Results}

The concentration of $\mathrm{C} 4$ in the proband's serum measured functionally over a 2 -yr period was $2-5 \%$ of normal and as antigen it was 3-9\% of normal. Antigenic C4 levels in EDTA plasma samples maintained at $37^{\circ} \mathrm{C}$ were $5-10 \%$ of normal. Table I presents the results of complement studies performed

Table I. Complement Protein Concentrations in the Patient with C4 Deficiency during Clinical Remission

\begin{tabular}{lrlcr}
\hline Protein & \multicolumn{1}{c}{ Patient } & $\begin{array}{l}\text { Functional }(\mathbf{F})^{*} \text { or } \\
\text { Immunochemical }(\mathbf{I}) \mp\end{array}$ & $\begin{array}{l}\text { Normal range } \\
(\bar{M} \pm 2 \text { SD) }\end{array}$ & $\begin{array}{l}\text { No. of } \\
\text { controls }\end{array}$ \\
\hline C1 & 186,000 & F & $190,000 \pm 88,000$ & 25 \\
C2 & 18,300 & F & $15,600 \pm 12,200$ & 10 \\
C3 & 6,600 & F & $8,100 \pm 5,200$ & 7 \\
& 106 & I & $123 \pm 54$ & 25 \\
C4 & 4,400 & F & $133,000 \pm 92,000$ & 10 \\
& 3 & I & $31.3 \pm 19$ & 25 \\
C5 & 44,000 & F & $54,800 \pm 48,000$ & 5 \\
C6 & 51,500 & F & $76,550 \pm 33,080$ & 7 \\
C7 & 50,600 & F & $80,560 \pm 54,000$ & 5 \\
C8 & 142,000 & F & $150,000 \pm 80,000$ & 9 \\
C9 & 80,000 & F & $86,000 \pm 28,000$ & 7 \\
P & 1.3 & I & $1.7 \pm 1.0$ & 9 \\
B & 25 & I & $18 \pm 12$ & 25 \\
H & $75 \S$ & I & $87 \pm 42$ & 20 \\
C4 & & & & 109 \\
Binding & & & $113 \pm 69$ & \\
protein & $42 \S$ & I & & \\
\hline
\end{tabular}

* Units per milliliter.

¥ Milligrams per deciliter.

$\S \%$ normal pooled serum. 
when the proband was in complete clinical remission and taking no medication. Total hemolytic complement was moderately reduced and averaged $50 \%$ of the normal mean (100 $\mathrm{U} / \mathrm{ml}$ ). Admixture of the patient's serum with an equal amount of normal human serum yielded a $\mathrm{CH} 50$ of $50-75 \%$ of the normal mean. Normal serum mixed $1: 3$ and 2:3 with serum from the proband yielded $\mathrm{C} 4$ hemolytic activities of 40 and $100 \%$ of normal serum, respectively. The proband's serum was $75-80 \%$ as lytic (C1 activity) as normal serum against EAC4 cells. When purified C4 (Cordis Laboratories, Miami, FL) was added to the patient's serum, the CH50 increased toward normal. The serum concentrations of all complement proteins measured were normal, except for C4. In particular, C2 and $C \overline{1}$ inhibitor were present in normal concentrations. In addition, as determined by immunofixation electrophoresis, the C4 present in the patient's serum had native electrophoretic mobility and could be typed as C4A3 QO; C4B1,2. In addition, SDS-polyacrylamide gel electrophoresis of $\mathrm{C} 4$ from "abnormal" family members showed subunit size that was no different from normal. This minimizes the possibility of an alteration of the $\mathrm{C} 4$ molecule by a major glycosylation or

Table II. Clotting Studies in a Patient with C4 Deficiency

\begin{tabular}{|c|c|c|}
\hline Test or protein & Patient & Normal* \\
\hline Clotting time, glass ( $\mathrm{min}$ ) & $18 \mathrm{~min}$ & $13-25 \mathrm{~min}$ \\
\hline Clotting time, polystyrene (min) & $145 \mathrm{~min}$ & $60-245 \min$ \\
\hline Bleeding time (min) & $5 \mathrm{~min}$ & $<9 \min$ \\
\hline Thrombin time $(s)$ & $30 \mathrm{~s}$ & $26-34 \mathrm{~s}$ \\
\hline Prothrombin time $(s)$ & $14.5 \mathrm{~s}$ & $14.7 \mathrm{~s}$ \\
\hline \multicolumn{3}{|c|}{ Activated partial thromboplastin } \\
\hline Fibrinogen & Grossly normal & - \\
\hline $\begin{array}{l}\text { Fibrin-stabilizing factor (Factor } \\
\text { XIII) }\end{array}$ & Present & - \\
\hline Prothrombin (\%) & 100 & $65-150$ \\
\hline \multicolumn{3}{|l|}{ Antihemophilic factor (Factor } \\
\hline VIII:C) (\%) & 144 & $46-216$ \\
\hline Hageman factor (Factor XII) (\%) & 56 & $100 \pm 28$ \\
\hline Plasma prekallikrein (\%) & 114 & $102 \pm 23$ \\
\hline \multicolumn{3}{|l|}{ High molecular weight } \\
\hline kininogen (\%) & 70 & $99 \pm 26$ \\
\hline Platelet count (per $\mu l)$ & 183,000 & $214,000 \pm 56,000$ \\
\hline Clot retraction (\%) & 60 & $60+$ \\
\hline Platelet factor 3 & Normal & - \\
\hline $\begin{array}{l}\text { Platelet retention by glass bead } \\
\text { columns (\%) }\end{array}$ & 80 & $>25 \%$ \\
\hline $\begin{array}{l}\text { Platelet agglutination by } \\
\text { ristocetin }\end{array}$ & Normal & - \\
\hline $\begin{array}{l}\text { Platelet aggregation by collagen, } \\
\text { ADP, epinephrine, thrombin, } \\
\text { and zymosan }\end{array}$ & Normal & - \\
\hline
\end{tabular}

* Range or mean $\pm \mathrm{SD}$.
Table III. Protease Inhibitor Concentrations in the Patient with C4 Deficiency

\begin{tabular}{lclc}
\hline Protein & Patient* & $\begin{array}{l}\text { Functional (F) or } \\
\text { Immunochemical (I) }\end{array}$ & $\begin{array}{l}\text { Normal range } \\
(\overline{\mathrm{M}} \pm 2 \text { SD) }\end{array}$ \\
\hline Cī inhibitor & 16.2 & I & $110.5 \pm 66.5$ \\
& $11.3 \ddagger$ & F & $7.2 \pm 2.2$ \\
$\alpha_{1}$-Antitrypsin & 73 & I & $100 \pm 53$ \\
$\alpha_{2}$-Macroglobulin & 85 & I & - \\
$\alpha_{1}$-Antichymotrypsin & 73 & I & - \\
$\alpha_{2}$-Antiplasmin & 110 & I & $98 \pm 15$ \\
Antithrombin III & 79 & F & $92 \pm 13$
\end{tabular}

* Concentrations expressed as percentage of normal pooled serum. ‡ Units per ml.

Table IV. C4 and C4 Binding Protein Concentrations in Individual Family Members

\begin{tabular}{llll}
\hline Individual & $\begin{array}{l}\text { C4 hemolytic } \\
\text { activity }\end{array}$ & $\begin{array}{l}\mathrm{C} 4 \\
\text { protein }\end{array}$ & $\begin{array}{l}\text { C4 binding } \\
\text { protein }\end{array}$ \\
\hline & $U / \mathrm{ml}$ & $\mathrm{mg} / \mathrm{dl}$ & $\% \mathrm{nl} \mathrm{pool}$
\end{tabular}

Members with normal values

$\begin{array}{lrrr}\text { I-3 } & 136,000 & 49 & 115 \\ \text { I-4 } & 156,000 & 35 & 80 \\ \text { I-7 } & 70,000 & 32 & 85 \\ \text { I-9 } & 167,000 & 71 & 120 \\ \text { I-10 } & 129,000 & 43 & \text { ND } \\ \text { II-1 } & 78,000 & 19 & \text { ND } \\ \text { II-3 } & 112,000 & 37 & 92 \\ \text { II-4 } & 66,000 & 19 & 80 \\ \text { II-5 } & 61,000 & 18 & 60 \\ \text { II-7 } & 89,000 & 19 & 65 \\ \text { II-12 } & 167,000 & 43 & 70 \\ \text { II-13 } & 156,000 & 32 & 115 \\ \text { II-14 } & 47,000 & 18 & 80 \\ \text { III-3 } & 55,000 & 10 & 65\end{array}$

Members with hemolytic and immunochemical C4 concentrations at least 2 SD below normal

$\begin{array}{lrcc}\text { I-5 } & 2,800 & 2.5 & 52 \\ \text { I-6 } & 29,000 & 12 & 70 \\ \text { II-2 } & 20,000 & 6 & 55 \\ \text { II-6 } & 32,000 & 7 & 65 \\ \text { II-9 } & 27,000 & 6 & 55 \\ \text { II- } 10^{*} & 4,400 & 3 & 42 \\ \text { II-11 } & 28,000 & 9 & 80\end{array}$

Normals
(10)
$133,000 \pm 92,000(2 \mathrm{SD})$
$31.3 \pm 19(2 \mathrm{SD})$

ND, not determined.

* Proband. 
postsynthetic change. The electrophoretic mobility of the Ci inhibitor in serum of the proband and all family members was normal. The concentration of $\mathrm{C} 4$ binding protein was decreased to $42 \%$ of normal. The patient's serum and erythrocytes were positive for Chido and Rodgers antigens.

No family members, except the proband, had clinical evidence of immune complex disease, and sera from family members were all negative for CIC (except for one). In the proband, CIC were detectable only during periods of increased lupus activity. However, decreased C4 levels in the proband were unrelated to $\mathrm{CIC}$ and/or level of disease activity. Lowlevel CIC were detected in only one family member (II-6). These were transient, and were not associated with clinical disease or decreased levels of $\mathrm{C} 3$ or $\mathrm{C4}$. Because of the clinical abnormalities of the proband in this study, a comprehensive evaluation of hemostasis was performed (Table II). No abnormalities were detected except a reduced titer of Hageman factor (Factor XII), which was $56 \%$ of normal. Since her mother also had an intermediate titer of Hageman factor, the patient may be a heterozygote for Hageman factor deficiency.

Because the low $\mathrm{C} 4$ concentration in the proband's plasma might be explained by an uninhibited proteolytic attack on $\mathrm{C4}$, a number of protease inhibitors were studied in the patient's plasma or serum. The concentrations of $C \overline{1}$ inhibitor, $\alpha_{1}$-antitrypsin, $\alpha_{1}$-antichymotrypsin, $\alpha_{2}$-macroglobulin, $\alpha_{2}$-antiplasmin, and antithrombin III were all within normal limits (Table III).
Studies in the patient's family revealed that six other members had hemolytic and immunochemical C4 concentrations below the normal range defined as the mean value \pm 2 SD (Table IV). It is evident from the pedigree that the individuals with low $\mathrm{C} 4$ levels occurred in four subfamilies, all on the paternal side (Fig. 1). A paternal uncle (I-5) had an even lower serum $\mathrm{C} 4$ concentration than the proband. Of the father's three living siblings, two had C4 deficiency. One of two children of a deceased paternal uncle had C4 deficiency as did the patient's brother. Two of seven of the affected paternal uncle's children also had C4 deficiency. Thus, in this family, six of thirteen of the patient's relatives at risk, four males and two females, had C4 deficiency and there was maleto-male transmission of this trait. The pattern of inheritance is thus most likely autosomal dominant.

No evidence for linkage between $\mathrm{C} 4$ deficiency as a dominant trait and the MHC or other sixth chromosome markers could be obtained. In particular, there was neither linkage nor any association whatsoever between $\mathrm{C} 4$ genetic types and $\mathrm{C} 4$ deficiency. Although almost all affected individuals had one (of four) null C4 alleles and one (I-6) had two, this was also true of many family members with normal $\mathrm{C} 4$ levels.

\section{Discussion}

The form of $\mathrm{C} 4$ deficiency in the present family differs strikingly from that in previously described families (1-10) in

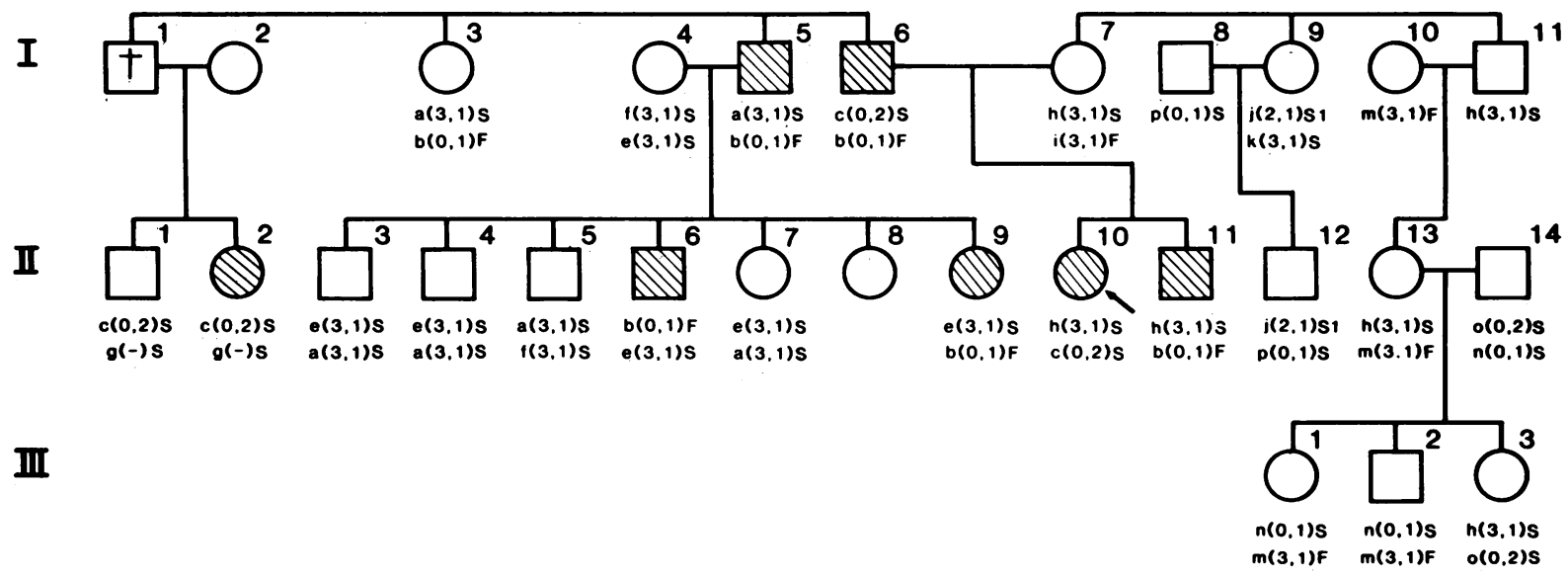

Figure 1. The family with C4 deficiency. Males are shown as squares, females as circles. Individuals with serum hemolytic and immunochemical C4 levels more than 2 SD below the normal mean are shown as cross-hatched symbols. The proband is indicated by an arrow. Major histocompatibility complex haplotypes are given below each symbol as a lower case letter. $\mathrm{C} 4$ alleles are given within parentheses in abbreviated form as C4A and C4B types with " 0 " for the null allele $\mathrm{Q} 0$. After the $\mathrm{C} 4$ types, $\mathrm{BF}$ types are given. The full haplotypes are:

$\mathrm{a}(3,1) \mathrm{S}=\mathrm{HLA}-\mathrm{A} 2, \quad \mathrm{~B} 40(61), \mathrm{Cw} 2, \mathrm{DR} 7,(C 4 A 3, B 1)$ BFS $\mathrm{b}(0,1) \mathrm{F}=\mathrm{HLA}-\mathrm{A} 2, \quad \mathrm{~B} 17(58), \mathrm{Cw} 3, \mathrm{DR} 6,(C 4 A Q 0, B 1) \mathrm{BFF}$. $\mathrm{c}(0,2) \mathrm{S}=$ HLA-A3 $, \quad \mathrm{B} 27, \quad \mathrm{Cw} 2, \quad(C 4 A Q 0, B 2) \mathrm{BFS}$. $\mathrm{e}(3,1) \mathrm{S}=$ HLA-A28, B12(44),Cw7,DR5, (C4A3,BI) BFS. $\mathrm{f}(3,1) \mathrm{S}=$ HLA-A9(24),B40(61),Cw2,DR6,(C4A3,B1) BFS. $\mathbf{g}(-) \mathrm{S}=$ HLA-A2, B12(44), $\mathrm{h}(3,1) \mathrm{S}=\mathrm{HLA}-\mathrm{A} 31, \quad \mathrm{~B} 40, \quad \mathrm{Cw} 3, \quad(C 4 A 3, B 1)$ BFS $\mathrm{i}(3,1) \mathrm{F}=\mathrm{HLA}-\mathrm{A} 24, \quad \mathrm{~B} 7, \quad(C 4 A 3, B 1)$ BFF. $\mathrm{j}(2,1) \mathrm{S} 1=$ HLA-A $1, \quad \mathrm{Bx}, \quad(C 4 A 2, B 1)$ BFS. 1 $\mathrm{k}(3,1) \mathrm{S}=\mathrm{HLA}-\mathrm{A} 2, \quad \mathrm{~B} 12, \quad(C 4 A 3, B 1)$ BFF. $\mathrm{m}(3,1) \mathrm{F}=\mathrm{HLA}-\mathrm{A} 1, \quad \mathrm{By}, \quad(C 4 A 3, B 1)$ BFF . $\mathrm{n}(0,1) \mathrm{S}=$ HLA-A $, \quad \mathrm{B} 8, \quad(C 4 A Q 0, B 1) \mathrm{BFS}$. o(0,2)S = HLA-A28, B40, $\quad(C 4 A Q 0, B 1) B F S$. $\mathrm{p}(0,1) \mathrm{S}=\mathrm{HLA}-\mathrm{A} 9(24), \mathrm{B} 13, \quad$ Cw6, $\quad(C 4 A Q 0, B 1) \mathrm{BFS}$. 
a number of ways. In the previous families, C4 deficiency was complete and C4 was not detectable either functionally or immunochemically. In the present family, some $\mathrm{C} 4$ was found in the serum of each affected individual and was present at concentrations of $2-24 \%$ of normal. Immunofixation and SDSPAGE studies indicate that the net surface change on the C4 molecule was as predicted from the allotypes and family studies and that no major glycosylation difference was present. In "classical" C4 deficiency, inheritance is recessive and carriers have, on average, about $50 \%$ of normal levels, although the range is so wide that serum concentration alone is a poor guide to detecting heterozygotes $(3,16)$ in such families. Classic C4 deficient individuals have inherited two double-null $C 4$ halplotypes $\left(C 4 A^{*} Q 0 ; C 4 B^{*} Q 0\right)(16)$. However, the form of C4 deficiency described here is inherited as a dominant trait, is independent of $\mathrm{C} 4$ structural gene types and null alleles and is not linked to the MHC or other closely associated loci of the sixth human chromosome. The present patient, like those with classical C4 deficiency, has systemic lupus erythematosus. However, the six relatives of our patient with decreased C4 have no signs of lupus or other collagen-vascular disease, suggesting that the association is by chance in this family.

Studies of the coagulation system in this family revealed only that the proband and her mother were probable heterozygotes for Hageman factor deficiency. Since there was no correlation between this abnormality and $\mathrm{C} 4$ levels in the family, it must be regarded as coincidental.

The only previously recognized complement deficiency state to be inherited as an autosomal dominant trait is hereditary angioneurotic edema (36) and it is associated with reduced C4 levels. Therefore, care was taken to exclude this possibility in the present family. No family member had experienced any symptoms of angioneurotic edema. $C \overline{1}$ inhibitor serum concentrations were normal by immunochemical and functional assays and had normal electrophoretic mobility (37) in all family members. Functionally measured $\mathrm{C} 2$ levels were normal in all subjects. $\mathrm{C} 4$ was in its native state in serum from all deficient persons. These observations make it unlikely that an abnormal $\mathrm{C}^{\overline{1}}$ inhibitor molecule is the cause of $\mathrm{C} 4$ deficiency in this family. The slightly reduced $\mathrm{C} 4$ binding protein concentrations in the serum of some individuals with markedly reduced $\mathrm{C} 4$ levels suggest $\mathrm{C} 4$ consumption by some uninhibited protease as the basis of the abnormality. However, the concentrations of a number of protease inhibitors such as $\alpha_{1}$-antitrypsin, $\alpha_{1}$-antichymotrypsin, $\alpha_{2}$-antiplasmin, antithrombin III, and $\alpha_{2}$-macroglobulin were normal in all sera from affected individuals.

\section{Acknowledgments}

We thank Ms. Deborah Marcus, Rosanne Stein, Cathy Ramaika, and Barbara Everson for expert technical assistance. We wish to acknowledge the great help of Marian Lewis, Rh Laboratory, University of Manitoba, Winnipeg, Canada for performing the Chido, Rodgers, and other erythrocyte antigen assays, and Dr. Eloise Giblett, Puget Sound Blood
Bank, Seattle, Washington for performing the glyoxalase, $\mathrm{PGM}_{\mathbf{3}}$, and other enzyme phenotyping.

This research was supported in part by a Clinical Research Center grant (RR00080) from the Division of Research Resources of the National Institutes of Health; by U. S. Public Health Service National Institutes of Health grants HL-01661, AI-14157, AM-26844, and HL29583; and by a grant from the American Heart Association to Dr. Ratnoff.

\section{References}

1. Hauptmann, G., E. Grosshans, and E. Heid. 1974. Lupus érythémateux aigus et déficits héréditaires en complément: a propos d'un cas par déficit complet en C4. Ann. Dermatol. Syphilgr. 101:479496.

2. Rittner, C., G. Hauptmann, H. Grosse-Wilde, E. Grosshans, M. M. Tongio, and S. Mayer. 1975. Linkage between HL-A (major histocompatibility complex) and genes controlling the synthesis of the fourth component of complement. In Histocompatibility Testing. F. Kissmeyer-Nielson, editor. Munksgaard, Copenhagen. 945-954.

3. Ochs, H. D., S. I. Rosenfeld, E. D. Thomas, E. R. Giblett, C. A. Alper, B. Dupont, J. G. Schaller, B. C. Gilliland, J. A. Hansen, and R. J. Wedgwood. 1977. Linkage between the gene (or genes) controlling synthesis of the fourth component of complement and the major histocompatibility complex. N. Engl. J. Med. 296:470-475.

4. Tappeiner, G., S. Scholz, J. Linert, E. D. Albert, and K. Wolff. 1978. Hereditary deficiency of the fourth component of complement: study of a family. Cutaneous Immunopathology. INSERM (Inst. Natl. Sante Rech. Med.) Colloq. 80:399-404.

5. Ballow, M., R. H. McLean, M. Einarson, S. Martin, E. J. Yunis, B. Dupont, and G. J. O'Neill. 1979. Hereditary C4 deficiency-genetic studies and linkage to HLA. Transplant. Proc. 11:1710-1712.

6. Urowitz, M. B., D. D. Gladman, and J. O. Minta. 1981. Systemic lupus erythematosus in a patient with $\mathrm{C} 4$ deficiency. J. Rheumatol. 8:741-746.

7. Minta, J. O., M. B. Urowitz, D. D. Gladman, T. Irizawa, and W. D. Biggar. 1981. Selective deficiency of the fourth component of complement in a patient with systemic lupus erythematosus (SLE): immunochemical and biological studies. Clin. Exp. Immunol. 45:7280.

8. Trappeiner, G., H. Hintner, S. Scholz, E. Albert, J. Linert, and K. Wolff. 1982. Systemic lupus erythematosus in hereditary deficiency of the fourth component of complement. J. Am. Acad. Dermatol. 7:66-79.

9. Kjellman, M., A.-B. Laurell, B. Löw, and A. G. Sjöholm. 1982. Homozygous deficiency of $\mathrm{C} 4$ in a child with a lupus erythematosus syndrome. Clin. Genet. 22:331-339.

10. Mascart-Lemone, F., G. Hauptmann, J. Goetz, J. Duchateau, G. Delespesse, B. Vray, and I. Dab. 1983. Genetic deficiency of the fourth component of complement presenting with recurrent infections and a SLE-like disease: genetical and immunological studies. Am. J. Med. 75:295-304.

11. O'Neill, G. J., S. Y. Yang, and B. Dupont. 1978. Two HLAlinked loci controlling the fourth component of human complement. Proc. Natl. Acad. Sci. USA. 75:5165-69.

12. O'Neill, G. J., S. Y. Yang, J. Tegoli, R. N. Berger, and B. Dupont. 1978. Chido and Rodgers blood groups are distinct antigenic components of human complement C4. Nature (Lond.). 273:668-70.

13. Awdeh, Z. L., D. Raum, and C. A. Alper. 1979. Genetic 
polymorphism of human complement C4 and detection of heterozygotes. Nature (Lond.). 282:205-207.

14. Awdeh, Z. L., and C. A. Alper. 1980. Inherited structural polymorphism of the fourth component of human complement. Proc. Natl. Acad. Sci. USA. 77:3576-80.

15. Roos, M. H., E. Mollenhauer, P. Démant, and C. Rittner. 1982. A molecular basis for the two locus model of human complement component C4. Nature (Lond.). 298:854-56.

16. Awdeh, Z. L., H. D. Ochs, and C. A. Alper. 1981. Genetic analysis of C4 deficiency. J. Clin. Invest. 67:260-263.

17. Ballow, M., R. H. McLean, E. J. Yunis, Z. L. Awdeh, G. J. O’Neill, M. Einarson, and C. A. Alper. 1981. C4 polymorphism and HLA linkage: studies in a family with hereditary C4 deficiency. Clin. Immunol. Immunopathol. 20:354-360.

18. Rapp, H. J., and T. Borsos. 1970. Molecular basis of complement action. Appleton-Century-Crofts, New York.

19. Nelson, R. A., Jr., J. Jensen, and I. Gigli. 1966. Methods for the separation, purification and measurement of nine components of hemolytic complement in guinea-pig serum. Immunochemistry. 3:111135.

20. Rosenfeld, S. I., M. E. Kelley, and J. P. Leddy. 1976. Hereditary deficiency of the fifth component of complement in man. I. Clinical, immunochemical, and family studies. J. Clin. Invest. 57:1626-1634.

21. Laurell, C.-B. 1966. Quantitative estimation of proteins by electrophoresis in agarose gel containing antibodies. Anal. Biochem. 15:45-52.

22. Pensky, J., and I. H. Lepow. 1977. Complement-related proteins. In Methods in Immunology and Immunochemistry. C. A. Williams, and M. Chase, editors. New York, Academic Press, 1977, IV:242-250.

23. Zubler, R. H., G. Lange, P. H. Lambert, and P. D. Miescher. 1976. Detection of immune complexes in unheated sera by a modified ${ }^{125}$ I-Clq binding test. J. Immunol. 116:232-235.

24. Amos, D. B. Cytocytoxicity Testing. In NIAID Manual of Tissue Typing Techniques. J. G. Ray, editor. N114 publication \#80$545, \mathrm{pg} 42-45,1980$.

25. Lowry, R., J. Goguen, C. B. Carpenter, T. B. Strom, and M. R. Garovoy. 1979. Improved B cell typing for HLA-DR using nylon wool column enriched B lymphocyte preparations. Tissue Antigens. 14:325-329.
26. Alper, C. A., T. Boenisch, and L. Watson. 1972. Genetic polymorphism in human glycine-rich beta-glycoprotein. J. Exp. Med. 135:68-80.

27. Alper, C. A. 1976. Inherited structural polymorphism in human C2. Evidence for genetic linkage between $C 2$ and Bf. J. Exp. Med. 144:1111-1115

28. Kompf, J., S. Bissbort, S. Gussmann, and H. Ritter. 1975. Polymorphism of red cell glyoxalase-1 (E.C.: 4.4.1.5): a new genetic marker in man: investigation of 169 mother-child combinations. Humangenetik. 27:141-143.

29. Goedde, H. W., and M. Stahn. 1974. PGM $\left(\mathrm{PGM}_{1}, \mathrm{PGM}_{2}\right)$ phenotyping in human leucocytes with a simplified method. Humangenetik. 22:143-145.

30. Forman, W. B., O. D. Ratnoff, and M. H. Boyer. 1968. An inherited qualitative abnormality in plasma fibrinogen. Fibrinogen Cleveland. J. Lab. Clin. Med. 72:455-472.

31. Ratnoff, O. D., and H. L. Nossel. Wasp sting anaphylaxis. Blood. In press.

32. Ratnoff, O. D., and B. Bennett. 1973. Clues to the pathogenesis of bleeding in von Willebrand's disease. N. Engl. J. Med. 289:11821183.

33. Jackson, D. P., R. C. Hartmann, and C. L. Conley. 1953. Clot retraction as a measure of platelet function. II. Clinical disorders associated with qualitative platelet defects (thrombocytopathic purpura). Bull. Johns Hopkins Hosp. 93:370-385.

34. Salzman, E. W. 1963. Measurement of platelet adhesiveness. A simple in vitro technique demonstrating an abnormality in von Willebrand's disease. J. Lab. Clin. Med. 62:724-735.

35. Spaet, T. H., and J. Cintron. 1965. Studies on platelet factor-3 availability. Br. J. Haematol. 11:269-275.

36. Donaldson, V. H., and R. R. Evans. 1963. A biochemical abnormality in hereditary angioneurotic edema: absence of serum inhibitor of C1-esterase. Am. J. Med. 35:37-44.

37. Rosen, F. S., C. A. Alper, J. Penksy, M. R. Klemperer, and V. H. Donaldson. 1971. Genetically determined heterogeneity of the $\mathrm{Cl}$ esterase inhibitor in patients with hereditary angioneurotic edema. J. Clin. Invest. 50:2143-2149. 